\title{
The effect of different dietary vitamin and mineral levels on certain production parameters, including egg shell characteristics of breeding ostriches
}

\author{
T.S. Brand ${ }^{1,2 \#}$, G.A. Tesselaar ${ }^{2}$, L.C. Hoffman ${ }^{2}$ \& Z. Brand ${ }^{1}$ \\ ${ }^{1}$ Directorate: Animal Science, Department of Agriculture, Western Cape, Private Bag X1, Elsenburg, 7607, South Africa \\ ${ }^{2}$ Department of Animal Sciences, Stellenbosch University, Private Bag X1, Matieland, 7602, South Africa
}

(Received 4 January 2014; Accepted 5 June 2014; First published online 24 August 2014)

\begin{abstract}
Copyright resides with the authors in terms of the Creative Commons Attribution 2.5 South African Licence.
See: http://creativecommons.org/licenses/by/2.5/za

Condition of use: The user may copy, distribute, transmit and adapt the work, but must recognise the authors and the South African Journal of Animal Science.
\end{abstract}

\begin{abstract}
Earlier studies on breeding birds indicated no effect of dietary energy-content on feed intake. This observation is contradictory to results for other animals and/or poultry where feed intake decreases with an increase in dietary energy level. Literature revealed that a lack of certain nutrients may cause animals to consume more feed than necessary to satisfy their nutrient requirements for these limiting nutrients. In this study eight diet groups were evaluated. A standard commercial diet plus one of the following supplements: (i) Standard diet without a vitamin and mineral premix pack (control diet), (ii) with a normal premix pack, (iii) with normal vitamin and $2 \times$ trace elements ( $M \times 2$ ), (iv) with normal trace elements and $2 \times$ vitamins, (v) with a normal premix pack and limestone added as calcium source; (vi) with a normal premix pack and monocalcium phosphate added as phosphorus source, (vii) with a normal premix pack and soybean oilcake added as crude protein source, (viii) with a normal premix pack and linseed added as a fatty acid source. Significant differences were recorded in the quantity of feed ingested by birds between the diet with surplus minerals ( $M \times 2)$ (Group 3) $(2.3 \pm 0.3 \mathrm{~kg} /$ bird/day), the diet with no vitamins and minerals added (Group 1$)$ $(2.7 \pm 0.3 \mathrm{~kg} / \mathrm{bird} / \mathrm{day})$ and the diet with added fatty acids in the form of linseed (Group 5) (2.9 \pm 0.5 $\mathrm{kg} / \mathrm{bird} /$ day). This indicates the possibility that ostriches may adjust feed intake to satisfy their mineral requirements. No statistically significant relationship was found between the thickness and strength of the shell. Significant differences in shell strength (mean value of 154.7, 109.9, 140.4, 142.7, 153.0, 143.4, 138.4 and $151.1 \mathrm{~N} / \mathrm{cm}^{2}$, respectively) were found between all treatments, but no specific pattern could be identified. Results further revealed no effect of dietary treatment on egg production, dead-in-shell eggs (DIS), infertile eggs or chick production. Further experiments that include certain dietary treatments during the five months rest period are currently being done to quantify the effect of the addition of minerals and vitamins during this period on the production of breeding ostriches.
\end{abstract}

Keywords: Eggshell strength; feed intake, minerals, vitamins

\#Corresponding author: tersb@elsenburg.com

\section{Introduction}

Cooper et al. (2004) stated that most ostrich performance problems relating to fertility can be traced back to an inadequate breeder diet. Approximately $75 \%$ of a producer's running costs can generally be attributed to that of the breeder birds' nutrition (Brand et al., 2002b; Aganga et al., 2003; Kritzinger, 2011). Correct formulation of these diets, to ensure that adequate amounts of vitamins and trace elements are supplied, will then prevent feed wastage and increase profitability. The nutrient requirements of breeding ostriches are not as well-known as for other species and further research into the quantification of the nutrient requirements for optimal production and reproduction is thus required. Earlier studies on breeding ostriches have indicated no effect of dietary energy content on feed intake. This observation is contradictory to results for other animals and/or poultry (March et al., 1984). Furthermore, the literature has revealed that a lack of certain nutrients may cause animals to consume more feed in order to satisfy their nutrient requirements for these lacking nutrients (Brand et al., 2010). Supplementation of feed then generally occurs in the form of added premix packages which contain vitamins, minerals and other trace elements.

Vitamins have been defined by McDowell (1989) as a group of complex organic compounds, found in minute quantities in natural foodstuffs, essential to the normal metabolism and, when lacking in the diet, resulting in certain deficiency diseases. Minerals, on the other hand, are inorganic elements that form part of 
the ash portion of the feeds and are just as important as vitamins (Underwood, 1981). Minerals generally have four functions in the body, namely structural, physiological, catalytic and regulatory (Suttle, 2010). In the past, extrapolated chicken data was deemed a reliable source of information for determining the nutrient requirements of breeding ostriches. Further studies have, however, shown this not always to be the case (Cilliers et al., 1998). A lack of certain vitamins and minerals, or an imbalance thereof, can cause reduced hatchability through its influence ultimately on the quality of the eggs produced (Wilson, 1997).

The content of the egg is deposited while still forming inside the female and is enclosed prior to the onset of lay in a thick, multipurpose layer of shell. Calcium is vital for the protection of the egg, as calcium carbonate $\left(\mathrm{CaCO}_{3}\right)$ is one of the main components of the shell - being deposited during its passage down the oviduct (Suttle, 2010). The external structure of an egg owes its strength to the dome principle and its functional properties include water vapour qualities, respiratory gas conductance, water loss and metabolic rate. The structural properties of an eggshell include its thickness, porosity and mass density, as well as the surface area of the egg - with all these properties being intimately related to the weight of the egg and therefore to each other. All these structural and functional properties then need to function in synchrony with the metabolic growth of the embryo, in order to ensure the successful hatching of a viable chick at the end of the incubation period. The increased mortality of embryos in eggs that lose too much or too little weight in the form of moisture during the first week of incubation is indicative of this (Ar et al., 1979). Embryos in eggs with low-quality shells also have a higher risk of stunted growth due to infection caused by pathogens invading the egg through the shell (Wilson, 1997).

Romanhoff \& Romanhoff (1949) reported that the external characteristics of the avian egg are influenced by hereditary, physiological, as well as environmental factors. Hamilton (1982) then defined shell strength as the ability of the egg to withstand externally applied forces without cracking or breaking. Eggshell quality tests are mainly performed on domestic chicken eggs (Gallus domesticus) and correlated with factors, such as the diet in general or specific supplement inclusions such as calcium or phosphorus (Ar et al., 1979). The main factor affecting the strength of the hen eggshell is the thickness of the shell (Romanhoff \& Romanhoff, 1949; Tyler, 1969; Voisey \& Hunt, 1974). This is still to be proven for ostrich eggs. Ar et al. (1979), however, did prove that a simple, positive linear correlation between shell strength and egg mass does exist, with the correlation being higher for larger eggs, such as the eggs of an ostrich.

\section{Materials and Methods}

The trial for this study was conducted at the Oudtshoorn Research farm in Oudtshoorn, South Africa during the breeding season of 2009. Ninety-six breeding pairs of ostriches were divided into eight treatment groups of 12 breeding pairs each, in order to determine the effect of the experimental diets on the reproductive parameters and feed intake. The eight different diets were created by adding different levels of certain supplements to a standard commercial breeding diet. These supplements included extra vitamins, trace elements, minerals ( $\mathrm{Ca}$ and $\mathrm{P}$ ), crude protein (amino acids), and fatty acids at different inclusion levels. The 8 diets that were provided were as follows: (i) The standard diet without a premix pack (control diet, Treatment 1), (ii) with a normal premix pack (Premix 1, Treatment 2), (iii) with vitamins and $2 \times$ trace elements (Premix 3, Treatment 3), (iv) with trace elements and $2 \times$ vitamins (Premix 2, Treatment 4), (v) with a normal premix pack and added limestone as a source of calcium (Treatment 5), (vi) with a normal premix pack and added monocalcium phosphate as a source of phosphorus (Treatment 6), (vii) with a normal premix pack and added soybean oilcake as a source of crude protein (Treatment 7), and (viii) with a normal premix pack and added linseed as a source of fatty acids (Treatment 8).

The age of the birds varied from 2 to 9 years. The ostrich breeding pairs were divided into the treatment groups in such a way as to ensure an even distribution of breeding pair age, as well as estimated breeding values for egg production. The breeding pairs were maintained in breeder camps of 0.25 hectare per pair and received the experimental diets ad libitum (Van Niekerk, 1996). The dietary protein level was kept constant at $140 \mathrm{~g} / \mathrm{kg}$ and the metabolisable energy at $9 \mathrm{MJ} \mathrm{ME} / \mathrm{kg}$ feed. These levels were in accordance with the levels required for breeding ostriches to maintain body condition and egg production (Brand et al., 2002a; 2002b; 2002c; 2003).

Listed in Table 1 is the raw material content and nutritional composition of the eight different formulated diets which were fed to the breeding pairs in the breeding season from mid-May to midDecember. The nutrient composition of each diet was determined using a Near Infrared Reflectance Analyser (Bran \& Luebbe, 1994). In Table 2 the different vitamin and mineral levels of the three different premixes are set out. The breeding pairs were fed twice a week and all feed refusals were weighed back once a month to ensure an accurate feed intake determination. Ostrich eggs were collected twice a day, weighed, identified and stored in a cool room at $17{ }^{\circ} \mathrm{C}$, with a relative humidity $(\mathrm{RH})$ of $70 \%$, until further analysis. All production and reproduction records were kept, including the total egg production and chick production. 
Table 1 Raw material content and nutritional composition of the eight different experimental diets (kg/ton)

\begin{tabular}{|c|c|c|c|c|c|c|c|c|}
\hline \multirow{2}{*}{ Ingredients } & \multicolumn{8}{|c|}{ Diet number } \\
\hline & $1^{a}$ & $2^{b}$ & $3^{c}$ & $4^{d}$ & $5^{e}$ & $6^{f}$ & $7^{g}$ & $8^{h}$ \\
\hline Lucerne & 670 & 670 & 670 & 670 & 670 & 670 & 670 & 670 \\
\hline Maize & 167 & 167 & 167 & 167 & 167 & 167 & 167 & 167 \\
\hline Canola oilcake meal & 50 & 50 & 50 & 50 & 50 & 50 & 50 & 50 \\
\hline Soya oilcake meal & 0 & 0 & 0 & 0 & 0 & 0 & 50 & 0 \\
\hline Linseed & 0 & 0 & 0 & 0 & 0 & 0 & 0 & 50 \\
\hline Limestone & 25 & 25 & 25 & 25 & 50 & 25 & 25 & 25 \\
\hline Molasses & 50 & 50 & 50 & 50 & 50 & 50 & 50 & 50 \\
\hline Dicalcium phosphate $(18 \% \mathrm{P})$ & 22.5 & 22.5 & 22.5 & 22.5 & 22.5 & 22.5 & 22.5 & 22.5 \\
\hline Monocalcium phosphate (21\% P) & 0 & 0 & 0 & 0 & 0 & 25 & 0 & 0 \\
\hline Common salt ( $\mathrm{NaCl})$ & 10 & 10 & 10 & 10 & 10 & 10 & 10 & 10 \\
\hline Vitamin \& mineral premix 1 & 0 & 3.5 & 0 & 0 & 3.5 & 3.5 & 3.5 & 3.5 \\
\hline Vitamin \& mineral premix 2 & 0 & 0 & 0 & 4.5 & 0 & 0 & 0 & 0 \\
\hline Vitamin \& mineral premix 3 & 0 & 0 & 3.5 & 0 & 0 & 0 & 0 & 0 \\
\hline \multicolumn{9}{|l|}{ Nutrients } \\
\hline Crude protein & 13.8 & 14.3 & 14.2 & 14.2 & 14.4 & 14.1 & 15.1 & 14 \\
\hline Fat & 2.2 & 2.1 & 2.1 & 2.2 & 2.2 & 2.2 & 2.2 & 3.3 \\
\hline Fibre & 20 & 19.6 & 19.6 & 19.7 & 19.7 & 20 & 19.1 & 18.8 \\
\hline
\end{tabular}

\footnotetext{
${ }^{\mathrm{a}}$ Treatment 1 = no premix pack;

${ }^{\mathrm{b}}$ Treatment $2=3.5 \mathrm{~kg}$ normal vitamin and mineral premix pack;

${ }^{\mathrm{c}}$ Treatment $3=$ minerals $\times 2$ and normal vitamin content at $3.5 \mathrm{~kg}$;

${ }^{\mathrm{d}}$ Treatment $4=$ vitamins $\times 2$ and normal mineral content at $4.5 \mathrm{~kg}$;

${ }^{\mathrm{e}}$ Treatment $5=3.5 \mathrm{~kg}$ premix pack with added limestone (calcium source);

${ }^{\mathrm{f}}$ Treatment $6=3.5 \mathrm{~kg}$ premix pack with added monocalcium phosphate (phosphorus source);

${ }^{9}$ Treatment $7=3.5 \mathrm{~kg}$ premix pack with added soya oilcake (crude protein/ amino acid source);

${ }^{\mathrm{h}}$ Treatment $8=3.5 \mathrm{~kg}$ premix pack with added linseed (fatty acid source).
}

During the trial period, three eggshell fragments per egg were collected from the 1466 ostrich eggs that hatched successfully. The surface area, shell thickness and eggshell strength were determined for all the egg shell fragments collected and the average of three fragments was taken as being representative of the egg. The eggshell fragments were all sampled from around the air sac area after the chick had hatched and were subsequently cleaned with distilled water and dried at room temperature. The area of the shell fragments was determined by a LICOR leaf area meter comprised of two separate components: an area meter sensor (Model LI-3000A) and a conveyer belt moving at a constant speed (Model LI-3050C). Due to the apparatus not being able to accommodate the thickness of the shell fragments it was necessary to trace the fragments on brown paper, cut out the traced areas and then send these paper copies through the machine. Shell strength was determined using an Instron texture machine (Model 4444), while thickness was determined to the nearest $0.01 \mathrm{~mm}$ with Mitutoyo Callipers (Model CD-8C). Dried shell membranes were included in the measurement of the shell thickness. A one-way ANOVA was performed on the data using Statgraphics.

\section{Results and Discussion}

Only the reproductive data of the breeding birds that bred for the entire breeding season of 203 days were used. Although the breeding birds received feed ad libitum, an average feed intake of $2.6 \pm 0.3 \mathrm{~kg} / \mathrm{bird}$ (mean \pm SE) per day was recorded for all the diets. This was low for ad libitum feed intake, when compared to the $3.7 \mathrm{~kg}$ feed/bird/day recorded by Olivier (2010).

The least square means $( \pm \mathrm{SE})$ and significant differences of the different characteristics of ostrich egg hatchability for the different treatments are summarised in Table 3 . Included in Table 4 are the least square 
means $( \pm$ SE) and significant differences of the ostrich eggshell fragment quality characteristics for the different dietary treatments.

Table 2 Composition of the three different premix levels used in the experimental ostrich diets

\begin{tabular}{|c|c|c|c|c|}
\hline Nutrient & unit & Premix 1 & Premix 2 & Premix 3 \\
\hline Vitamin A & mill IU & 16 & 32 & 16 \\
\hline Vitamin $D_{3}$ & mill IU & 2.5 & 5 & 2.5 \\
\hline Vitamin $B_{1}$ & gram & 2.5 & 5 & 2.5 \\
\hline Vitamin $B_{2}$ & gram & 6 & 12 & 6 \\
\hline Vitamin $\mathrm{B}_{6}$ & gram & 4.5 & 9 & 4.5 \\
\hline Folic Acid & gram & 1 & 2 & 1 \\
\hline Vitamin $\mathrm{B}_{12}$ & $\mathrm{mg}$ & 10 & 20 & 10 \\
\hline Vitamin E & gram & 30 & 60 & 30 \\
\hline Choline & gram & 480 & 960 & 480 \\
\hline Niacin & gram & 40 & 80 & 40 \\
\hline Pantothenic acid & gram & 16 & 32 & 16 \\
\hline Vitamin $\mathrm{K}$ & gram & 2.5 & 5 & 2.5 \\
\hline Biotin & $\mathrm{mg}$ & 100 & 200 & 100 \\
\hline Cobalt & $\mathrm{mg}$ & 100 & 100 & 200 \\
\hline Iodine & gram & 1 & 1 & 2 \\
\hline Selenium & $\mathrm{mg}$ & 300 & 300 & 600 \\
\hline Manganese & gram & 125 & 125 & 250 \\
\hline Copper & gram & 6 & 6 & 12 \\
\hline Zinc & gram & 100 & 100 & 200 \\
\hline Magnesium & gram & 45 & 45 & 90 \\
\hline Iron & gram & 30 & 30 & 60 \\
\hline Antioxidants $^{1}$ & gram & 100 & 100 & 100 \\
\hline Limestone carrier $^{2}$ & gram & 1173 & 1173 & 971 \\
\hline
\end{tabular}

${ }^{1}$ contains no vitamins and minerals; ${ }^{2}$ contains $36 \%$ calcium.

Results showed no significant effect of dietary treatment on total egg production, DIS, infertile eggs or chick production. There were also no significant differences in the body mass difference of males and females due to the effect of the dietary treatments. The levels of protein and energy $(140 \mathrm{~g} / \mathrm{kg}$ and $9 \mathrm{MJ}$ $\mathrm{ME} / \mathrm{kg}$, respectively) supplied were in accordance with the levels required by breeding ostriches to maintain egg production and body condition during the breeding season (Brand et al., 2002a; Brand et al., 2002b; Brand et al., 2002c; Brand et al., 2003). Significant differences $(P<0.05)$ were found in the quantity of feed ingested by the birds between the diets with surplus minerals $(M \times 2)$ (Treatment 3$)(2.3 \pm 0.3 \mathrm{~kg} / \mathrm{bird} / \mathrm{day})$ and the diet with no vitamins and minerals added $(2.7 \pm 0.3 \mathrm{~kg} / \mathrm{bird} /$ day) (Control or Treatment 1$)$. The main difference between these two diets was the presence of the vitamin and mineral premix pack. The decrease in feed intake observed in the group that received the $\mathrm{M} \times 2$ feed (Treatment 3 ) indicated the possibility that ostriches ingest feed to satisfy both vitamin and mineral requirements. It may also indicate that surplus minerals may create a feed that is less palatable. Significant differences $(P<0.05)$ were, however, also found between the diet with added fatty acids in the form of linseed $(2.9 \pm 0.5 \mathrm{~kg} / \mathrm{bird} /$ day) (Treatment 8$)$ and the diet with surplus minerals $(\mathrm{M} \times 2)(2.3 \pm 0.3 \mathrm{~kg} / \mathrm{bird} / \mathrm{day})$ (Treatment 3$)$. Although both these diets had a vitamin and mineral premix included, intake of the feed with the extra minerals added $(M \times 2)$ was lower. The possibility thus exists that ostriches ingest feed to satisfy mineral requirements if feed is supplied ad libitum.

No statistically significant relationship was found between the thickness and strength of the shell. This is in contradiction to findings with chicken eggs (Romanhoff \& Romanhoff, 1949; Tyler, 1969; Voisey \& Hunt, 
Table 3 Least square means $( \pm$ SE) of the different production parameters of breeding ostriches for the different treatments

\begin{tabular}{|c|c|c|c|c|c|c|c|c|c|}
\hline Treatment & $\begin{array}{c}\text { Total } \\
\text { egg } \\
\text { production }\end{array}$ & Min & Max & $\begin{array}{c}\% \\
\text { Infertile }\end{array}$ & \%DIS & $\begin{array}{l}\% \text { Chicks } \\
\text { hatched }\end{array}$ & $\begin{array}{c}\text { Male mass } \\
\text { difference* } \\
(\mathrm{kg})\end{array}$ & $\begin{array}{c}\text { Female mass } \\
\text { difference* } \\
(\mathrm{kg})\end{array}$ & $\begin{array}{c}\text { Feed } \\
\text { Ingested } \\
\text { (g/bird/day) }\end{array}$ \\
\hline 1 & $47.5 \pm 30.7$ & 0 & 83 & $17.4 \pm 19.6$ & $19.0 \pm 13.6$ & $35.5 \pm 27.0$ & $3.1 \pm 5.0$ & $-1.3 \pm 2.1$ & $2737.3^{a} \pm 97.8$ \\
\hline 2 & $56.5 \pm 23.4$ & 0 & 83 & $10.6 \pm 8.4$ & $23.3 \pm 18.0$ & $41.2 \pm 22.0$ & $4.0 \pm 2.8$ & $-6.7 \pm 2.4$ & $2531.6^{\mathrm{ab}} \pm 77.4$ \\
\hline 3 & $47.3 \pm 18.0$ & 17 & 73 & $27.0 \pm 32.3$ & $20.6 \pm 17.2$ & $33.9 \pm 24.4$ & $-0.5 \pm 3.6$ & $-9.5 \pm 3.2$ & $2272.0^{\mathrm{b}} \pm 97.0$ \\
\hline 4 & $59.5 \pm 21.5$ & 23 & 88 & $24.4 \pm 33.4$ & $19.3 \pm 13.8$ & $38.6 \pm 23.8$ & $5.1 \pm 0.5$ & $4.8 \pm 2.4$ & $2656.8^{\mathrm{ab}} \pm 88.4$ \\
\hline 5 & $44.0 \pm 20.7$ & 0 & 74 & $10.0 \pm 6.2$ & $29.7 \pm 16.1$ & $37.8 \pm 19.1$ & $3.7 \pm 0.3$ & $3.8 \pm 0.4$ & $2571.9^{\mathrm{ab}} \pm 96.6$ \\
\hline 6 & $45.8 \pm 20.1$ & 19 & 83 & $24.0 \pm 26.2$ & $18.3 \pm 13.3$ & $37.7 \pm 23.9$ & $-3.5 \pm 3.2$ & $-1.3 \pm 3.0$ & $2461.8^{\mathrm{ab}} \pm 50.1$ \\
\hline 7 & $44.8 \pm 26.7$ & 8 & 93 & $19.3 \pm 18.2$ & $22.0 \pm 15.4$ & $39.0 \pm 24.4$ & $7.5 \pm 3.3$ & $-7.2 \pm 2.9$ & $2546.6^{\mathrm{ab}} \pm 124.12$ \\
\hline 8 & $54.4 \pm 20.9$ & 14 & 79 & $13.1 \pm 10.1$ & $21.4 \pm 8.0$ & $49.4 \pm 20.2$ & $2.0 \pm 2.9$ & $-4.2 \pm 1.4$ & $2863.9^{\mathrm{a}} \pm 157.8$ \\
\hline
\end{tabular}

Table 4 Least square means $( \pm$ SE) and significant differences of different ostrich eggshell characteristics for the different treatments

\begin{tabular}{cccc}
\hline Diet & $\begin{array}{c}\text { Shell thickness } \\
(\mathbf{m m})\end{array}$ & Shell area $\left(\mathbf{c m}^{2}\right)$ & $\begin{array}{c}\text { Break strength } \\
\left(\mathbf{N} / \mathbf{~ c m}^{2}\right)\end{array}$ \\
\hline 1 & $1.8^{\mathrm{a}} \pm 0.01$ & $22.1 \pm 0.7$ & $154.7^{\mathrm{a}} \pm 2.3$ \\
2 & $1.6^{\mathrm{d}} \pm 0.03$ & $20.0 \pm 1.5$ & $109.9^{\mathrm{d}} \pm 4.3$ \\
3 & $1.8^{\mathrm{ac}} \pm 0.01$ & $22.0 \pm 0.8$ & $140.8^{\mathrm{c}} \pm 2.3$ \\
4 & $1.8^{\mathrm{c}} \pm 0.01$ & $22.0 \pm 0.6$ & $142.7^{\mathrm{a}} \pm 1.7$ \\
5 & $1.8^{\mathrm{a}} \pm 0.01$ & $22.1 \pm 0.9$ & $154.0^{\mathrm{a}} \pm 2.6^{\mathrm{c}}$ \\
6 & $1.8^{\mathrm{a}} \pm 0.01$ & $21.4 \pm 0.7$ & $143.4^{\mathrm{c}} \pm 2.5$ \\
7 & $1.7^{\mathrm{c}} \pm 0.01$ & $21.2 \pm 0.8$ & $138.4^{\mathrm{c}} \pm 2.3$ \\
8 & $1.8^{\mathrm{a}} \pm 0.01$ & $22.8 \pm 0.5$ & $151.6^{\mathrm{a}} \pm 1.4$ \\
\end{tabular}

${ }^{a, b, c}$ Least square means within columns with different superscripts differ significantly $(P<0.05)$. 
1974). Significant $(P \leq 0.05)$ differences in shell strength (mean values of $154.7,109.9,140.4,142.7,153.0$, $143.4,138.4$ and $151.1 \mathrm{~N} / \mathrm{cm}^{2}$ for the eight treatment groups, respectively) and shell thickness $(1.8,1.6,1.8$, 1.8, 1.8, 1.7 and $1.8 \mathrm{~mm}$, respectively) were found between treatments, but no specific pattern could be identified. If the ostrich eggshell is too strong and/or too thick, the appropriate egg weight loss in the form of moisture loss will not occur during incubation, causing the embryo to die. However, if the eggshell is too weak or too thin, pathogens may penetrate the egg, causing infections, and excessive moisture loss will occur during incubation, also causing chick mortalities (Wilson, 1997). An unfavourable shell structure will result in an increase in DIS eggs and/or a decrease in egg production due to longer intervals occurring between the laying of individual eggs (Brand et al., 2003b). The results of this study, however, revealed no effect of dietary treatment on egg production, DIS eggs, infertile eggs or chick production.

In the industry it is believed that higher levels of calcium in the feed will result in stronger eggshells and increase the occurrence of DIS eggs (Richards et al., 2000). In this study, no effect of a higher calcium level in the feed was recorded on the occurrence of DIS eggs, or the shell break strength.

\section{Conclusions}

No specific effect of any one of the tested parameters (additional vitamins, minerals, fatty acids and amino acids) were observed in the production parameters considered. Feed intake for the control diet and the diet with the added fatty acids was $20 \%$ higher than for the diet (Treatment 3 ) with the additional minerals $(M \times 2)$. The higher feed intake of the birds fed the control diet (no added minerals or vitamins) than those fed the diet with the additional minerals $(\mathrm{M} \times 2)$ may indicate that the birds in the first treatment group consumed feed to satisfy their need for minerals. If the additional minerals compensate for a higher feed intake, it may imply higher profitability levels for the ostrich producer. The difference between the linseed diet (Treatment 8) and the $M \times 2$ diet remains partly unexplained. Literature does, however, indicate that the provision of unsaturated fatty acids may depress the uptake of certain trace elements (Atteh \& Leeson, 1984). Overall it may be concluded that no major deficiencies of minerals, vitamins, fatty acids and amino acids in standard breeding ostrich diets can be identified using feed intake as an indicator. The provision of additional calcium did not affect the percentage DIS or the shell break strength of the ostrich eggs. The provision of minerals/vitamins during the 5 months rest period may, however, also play a role in the results obtained as certain vitamins and minerals can be stored in body organs. An experiment to test the effect of the provision of a vitamin/mineral premix during the rest period and the breeding period is currently being performed, since certain vitamins and minerals are stored in the body for relatively long periods of time.

\section{References}

Aganga., A.A., Aganga, A.O. \& Omphile, U.J., 2003. Ostrich feeding and nutrition. Pak. J. Nutr. 2, 60-67.

Ar, A., Rahn, H. \& Paganelli, C.V., 1979. The avian egg: mass and strength. Condor 81, 331-337.

Angel, C.R., 1993. Age changes in digestibility of nutrients in ostriches and nutrient profiles of ostrich and emu eggs as indicators of nutritional status of the hen and chick. Ass. Avian Vet.

Atteh, J.O. \& Leeson, S., 1984. Effects of dietary saturated or unsaturated fatty acids and calcium levels on performance and mineral metabolism of broiler chicks. Poult. Sci. 63, 2252-2260.

Bran \& Luebe, 1994. Operation Manual. Norderstedt, Germany.

Brand, T.S., Nel, K., Brand, Z. \& Van Schalkwyk, K., 2002a. Recent advances in ostrich nutrition in South Africa: effect of dietary energy and protein level on the performance of growing ostriches. S. Afr. J. Anim. Sci. 3, 1-8.

Brand, T.S., Olivier, T.R. \& Gous, R.M., 2010. The response in food intake and reproductive parameters of breeding ostriches to increasing dietary energy. S. Afr. J. Anim. Sci. 40, 434-437.

Brand, Z., Brand, T.S. \& Brown, C.R., 2002b. The effect of dietary energy and protein levels during a breeding season of ostriches (Strutio camelis domesticus), on production of the following season. S. Afr. J. Anim. Sci. 32, 226-230.

Brand, Z., Brand, T.S. \& Brown, C.R., 2002c. The effect of dietary energy and protein levels on body condition and production of breeding male ostriches. S. Afr. J. Anim. Sci. 32, 231-239.

Brand, Z., Brand, T.S. \& Brown, C.R., 2003. The effect of dietary energy and protein levels on production in breeding female ostriches. Br. Poult. Sci. 44, 598-606.

Brand, Z., Cloete, S.W.P., Brown, C.R. \& Malecki, I.A., 2008. Systematic factors affecting ostrich egg incubation traits. S. Afr. J. Anim. Sci. 38, 315-325.

Bronneberg, R.G.G., Stegeman, J.A., Vernooij, J.C.M., Dieleman, S.J., Decuypere, E., Bruggeman, V. \& Taverne, M.A.M., 2007. Changes in numbers of large ovarian follicles, plasma luteinizing hormone and estradiol- $17 \beta$ concentrations and egg production figures in farmed ostriches throughout the year. Theriogenology 67, 1492-1502. 
Cilliers, S.C., Hayes, J.P., Chwalibog, H., Sales, J. \& Du Preez, J.J., 1998. Determination of energy, protein and amino acid requirements for maintenance and growth in ostriches. Anim. Feed Sci. Technol. 72, 283-293.

Cooper, R.G. \& Mahroze, K.M., 2004. Anatomy and physiology of the gastro-intestinal tract and growth curves of the ostrich (struthio camelus). S. Afr. Anim. Sci. J. 75 (6), 491-498.

Cooper, R.G., Horbanczuk, J.O. \& Fujihara, N., 2004. Nutrition and feed management in the ostrich (Strutio camelus var domesticus). S. Afr. Anim. Sci. J. 75, 175-181.

Fraeye, I., Bruneel, C., Lemahieu, C., Buyse, J., Muyiaert, K. \& Foubert, I., 2012. Dietary enrichment of eggs with omega-3 fatty acids: A review. Food Res. Int. 48, 961-969.

Hamilton, R.M.G., 1982. Methods and factors that affect the measurements of egg shell quality. Poult. Sci. 61, 2022-2039.

Kritzinger, W.J., 2011. Allometric description of ostrich (Struthio camelus var.domesticus) growth and development. MSc thesis, Stellenbosch University, South Africa.

March, B.E., Austic, R.E., Jensen, L.S., Polin, D., Sell, J.R., Waibel, P.E. \& Waldroup, P.W., 1984. Nutrient Requirements of Poultry (8th ed.). National Academy Press, Washington D.C., USA.

McDowell, L.R., 1989. Vitamins in Animal Nutrition: Comparative Aspects to Human Nutrition. Academic Press, Inc.

Noble, R.C., Speake, B.K., McCartney, R., Foggin, C.M. \& Deeming, D.C., 1996. Yolk lipids and their fatty acids in the wild and captive ostrich (Struthio camelus). Comp. Biochem. Physiol. 113B (4), 753-756.

Olivier, T.R., 2010. Determination of the nutrient requirements of breeding ostriches. MSc (Agric) thesis, University of Stellenbosch, South Africa.

Olivier, T.R., Brand, T.S. \& Brand, Z., 2009. Influence of dietary energy level on the production of breeding ostriches. S. Afr. J. Anim. Sci. 39, 215-218.

Richards, P.D.G., Richards, P.A. \& Lee, M.E., 2000. Ultrastructural characteristics of ostrich eggshell: outer shell membrane and the calcified layers. J. S. Afr. Vet. Ass. 71, 97-102.

Romanhoff, A.L. \& Romanhoff, A.J., 1949. The Avian Egg. John Wiley \& Sons Inc, New York.

Suttle, N.F., 2010. Mineral Nutrition of Livestock. (4 ${ }^{\text {th }}$ ed). CABI, Cambridge, USA.

Tyler, C., 1969. Avian egg shells: their structure and characteristics. In: International Review of General and Experimental Zoology. Vol. 4. Eds: Felts, W.J.L. \& Harrison, R.J., Academic Press, New York.

Underwood, E.J., 1981. The Mineral Nutrition of Livestock. 2nd edition. Commonwealth Agricultural Bureaux.

Van Niekerk, A., 1996. Management of ostriches for egg production. Ministry of Agriculture, Water and Rural Development, Namibia.

Voisey, P.W. \& Hunt, J.R., 1974. Measurement of eggshell strength. J. Texture Stud 5 (2), 135-182.

Wilson, H.R., 1997. Effect of maternal nutrition on hatchability. Poult. Sci. 76, 137-143.

Yilmaz-Dikmen, B. \& Sahan, U., 2009. Physiology, endocrinology and reproduction: The relationship among age, yolk fatty acids content, and incubation results of broiler breeders. Poult. Sci. 88, 185-190. 